\title{
Bank Size, Credit Risk and Bank Profitability in Vietnam
}

\author{
Dieu Thi Thanh Tran ${ }^{a}$ \\ Quy Nhon University \\ Ha Thi Thu Phan ${ }^{b}$ \\ National Economics University
}

\begin{abstract}
This paper empirically examines the relationship between bank size, credit risk and profitability of Vietnam's commercial banks during the period from 2009 to 2018. By employing off-balance sheet items in the denominator when calculating return on assets, this paper highlights the role of off-balance sheet items in generating non-interest income as well as contributes to the literature on profitability measurement. By utilising the two-step system GMM, the outcomes show that credit risk has adverse impact on profitability and this impact tends to be slighter in large size banks. The negative correlation between bank size and profitability indicates that large banks tend to perform inefficiently rather than small banks. Also, we found evidence of a non-linear relationship between bank size and profitability, suggesting that bank size has improved bank profitability until it reaches the optimal threshold, which then decreases profitability.
\end{abstract}

Keywords: bank size, credit risk, non-linear ralationship, profitability, Vietnam JEL classification: C33, G21, G32

\section{Introduction}

A sound and healthy banking sector is essential in contributing to the financial system's stability as well as dealing with negative shocks (Athanasoglou, Brissimis, \& Delis, 2008). Therefore, the determinants of bank profitability have attracted the interests of researchers, especially in emerging countries as such Vietnam. During the last decade, the Vietnamese banking sector has experienced a strong restructuring wave to catch up with opportunities and threats in its operating environment. Foreign banks' penetration and requirements to meet Basel II have required Vietnamese banks to consolidate and enhance their financial strength. The most concerned issue associated with Vietnamese banks is the high level of non-performing loans (Vo, 2018) which leads to the decline of bank performance. Although the recent wave of mergers has helped form large banks, credit risk remains a profound issue for the Vietnamese banking system.

a Faculty of Finance-Banking and Business Administration, Quy Nhon University, 170 An Duong Vuong street, Quy Nhon, Binh Dinh, Vietnam. Email: tranthithanhdieu@qnu.edu.vn (Corresponding author)

b Institute of Banking and Finance, National Economics University, 207 Giai Phong street, Hai Ba Trung, Ha Noi, Vietnam. Email: hapt@neu.edu.vn

Article Info: Received 20 December 2019; Revised 2 July 2020; Accepted 9 September 2020 https://doi.org/10.22452/MJES.vol57no2.4 
The majority of studies on determinants of bank performance, such as Athanasoglou et al. (2008), Dietrich and Wanzenried (2011), Lee and Hsieh (2013), Nguyen and Nguyen (2018) and Trujillo-Ponce (2013) suggested a negative impact of credit risk on bank profitability. This adverse relationship can be explained by adverse selection effect and moral hazard proposed by Stiglitz and Weiss (1981). Banks ought to have provision for problem loans, leading to decline in before-tax incomes and profitability as well (Athanasoglou et al., 2008; Dietrich \& Wanzenried, 2011). By contrast, the skimping hypothesis suggests the positive effect of bad loans on bank performance because of the trade-off between short-term operating costs and future problem loans (Berger \& DeYoung, 1997). Banks are allowed to charge high interest rates for overdue loans, resulting in high interest income and greater profitability (Kosmidou, Tanna, \& Pasiouras, 2005; Lee, Yang, \& Chang, 2014). Bank size has been the essential factor in explaining bank performance, but its impact on profitability may be nonlinear. Too big to fail policy, unstable banking hypothesis and agency cost hypothesis are concerned with making intelligible on this relation (Boyd \& Runkle, 1993; Farhi \& Tirole, 2012; Laeven, Ratnovski, \& Tong, 2016). Bank size expansion helps banks take advantage of economies of scale to boost profitability (through diversification and network enlargement), but if the scale is too large, it may cause a backward effect on profitability due to administrative and other costs (Dietrich \& Wanzenried, 2011). Concerning the latest studies in Vietnam, Nguyen and Nguyen (2018) suggested that risky loans are causing high accumulation of problem loans and hence low profitability, whereas Batten and Vo (2019) concluded that Vietnamese banks with high proportion of risky loans might gain numerous net interest margin but return on equity tends to decline. Both studies highlighted the negative impact of bank size on profitability.

Because of the different samples and measurements, the antecedent researches are not explicit in clarifying the correlation between bank size, credit risk and bank profitability. By utilising data from 2009 to 2018 and the two-step system GMM estimator, this article aims to examine this relationship in the Vietnamese banking sector with some contributions. Firstly, while return on assets (ROA) and return on equity (ROE) may be important profitability measurements, this study proposes a new approach in measuring ROA which considers off-balance sheet items in the denominator. This can help enhance the literature in the era of expansion of offbalance sheet activities which brings about numerous non-interest incomes for banks. Secondly, the GMM estimator is more efficient than others to examine dynamic panel data, address potential endogeneity, heteroskedasticity and autocorrelation issues; especially, the two-step system GMM outperforms for unbalanced panel data and small sample. This technique is reliable and effective in discovering the non-linear relationship between bank size and profitability. Lastly, researches on emerging economics, such as Vietnam, have not been focused and disseminated. Vietnam should be an interesting environment to examine the relationship between bank size, credit risk and performance because of the following: the Vietnamese banking system plays a crucial role in supplying credit, but dynamic socio-economic developments and lack of management capacities have resulted in credit risks looming; Vietnam has just undergone a strong restructuring process, large-scale banks were created from mergers and the establishment of the Vietnam Asset Management Company (VAMC) has helped 
banks improve their non-performing loans situation. By 2020, Vietnamese banks ought to reform in accordance with Basel II. Also, this article provides some appropriate recommendations arising from the research outcomes.

This article is structured as follows. Section 2 reviews the literature related to the impact of credit risk and bank size on bank performance. Section 3 presents the methodology and data. Section 4 presents the regression results with two-step system GMM. Finally, Section 5 states conclusions and limitations as well.

\section{Literature Review}

\subsection{Credit Risk and Bank Profitability}

Credit risk is generally known as the likelihood of losses to the bank due to incidents such as borrowers violating debt repayment obligation, repudiation or delayed repayment (Basel, 2000). It may arise when a debtor is insolvent or refuses to pay the debt in full and on time (Coyle, 2000). Bank profitability reflects the financial health and operational efficiency as well as management capacity of a bank. To explicate the relationship between credit risk and bank profitability, Stiglitz \& Weiss (1981) suggested the information asymmetry theory which states that the relationship between credit risk and bank performance involves the interest rate: when the lending rate increases, the interest income increases and thus credit risk has a positive impact on profitability; but the inverse correlation may occur if the optimal lending rate threshold is exceeded. Lending rate also affects credit risk because of the customer classification (adverse selection effect), and the changes of interest rate may affect the borrower's behaviour (moral hazard). Berger \& DeYoung (1997) developed four hypotheses concerning this relationship: (i) banks have to pay more to address bad loans, resulting in low cost efficiency and negative impact on bank profitability (bad luck hypothesis); (ii) problem loans can occur due to poor managers who have poor skills in guaranteeing, monitoring and controlling loans, hence non-performing loans will be negatively correlated to bank profitability (bad management hypothesis); (iii) banks can save on short-term lending costs to maximise profits in the long term, they accept credit risk to get high profits, thus the correlation between credit risk and bank profitability should be positive (skimping behaviour hypothesis); (iv) low-capital banks respond to moral hazard encouragements by raising the riskiness of its loan portfolio, which generates higher average non-performing loans in the future (moral hazard hypothesis).

The impact of credit risk on bank profitability has been studied by many researchers with conflicting results. Angbazo (1997) suggested that US banks with more risky loans can earn higher net interest margins, implying a positive relationship between credit risk and performance. Kosmidou et al. (2005) stated that for UK banks with sound quality of loans, a high ratio of loan loss reserves implies a favourable impact of credit risk on bank profitability. Studies by Ammar and Boughrara (2019) and Olson and Zoubi (2011) pointed out that MENA banks are less likely to endure credit risk because they have offered great quality loans, hence suffering low losses from their lending activities. Ghanaian banks are allowed to charge extremely high lending rates, so despite of high credit risk, they have gained high profitability (Boahene, Dasah, \& Agyei, 2012). Lee 
et al. (2014) and Sufian and Habibullah (2009) revealed the same outcome in Asian countries, thus credit risk in high income countries is lower than in developing and emerging countries. In Vietnam, Batten and Vo (2019) also indicated Vietnamese banks reported a positive relationship between high credit risk and profitability. However, they recommended that this beneficial effect is in the short term, and the negative effect should be considered in the long term.

In contrast to these studies, others such as Athanasoglou et al. (2008), Dietrich and Wanzenried (2011), Kosmidou (2008) and Miller and Noulas (1997) showed that credit risk has a harmful effect on bank profitability. Increasing doubtful assets require banks to make loss provisions by allocating a significant portion of their before tax income, thus experiencing low profitability (Trujillo-Ponce, 2013). Low returns will be made by banks that do not properly implement the policy of identifying, assigning, measuring and managing credit risk (Pervan, Pelivan, \& Arnerić, 2015). Lee and Hsieh (2013), Liu and Wilson (2010), Mongid and Muazaroh (2017) and Sufian and Chong (2008) had the same view of the adverse correlation between credit risk and performance in Asian banks. They suggested that credit risk could be a principal determinant of bank profitability and should be taken with care. In some Asian countries, credit risk also has a negative impact on bank performance. Sufian \& Chong (2008) suggested that Philippines banks with higher non-performing loans might suffer lower profitability. Studies in Indonesia such as Ghalib (2018) and Lutfi and Suyatno (2019) indicated an adverse relationship between non-performing loans and bank performance due to the fact that banks have to spend more time, efforts and costs on managing problem loans. Malaysian banks also witnessed the deterioration of bank profitability because of bad loans (Trofimov, Md. Aris, \& Kho, 2018), but this impact is insignificant in the study by Lee (2018). In Vietnam, Nguyen and Nguyen (2018) pointed out that the greater the exposure to high-risk loans is, the higher the accumulation of overdue loans and reserves created and thus the lower the profitability will be. However, Nguyen (2018) found no statistically significant relationship between credit risk and bank performance in Vietnam.

The foregoing arguments lead us to develop two hypotheses of two opposite signs:

Hypothesis 1a: There is a positive impact of credit risk on bank performance.

Hypothesis $1 \mathrm{~b}$ : There is a negative impact of credit risk on bank performance.

\subsection{Bank Size and Bank Profitability}

The relationship between bank size and profitability is examined to determine potential economies or diseconomies of scale in the banking industry. The modern intermediation theory supposes that large banks often diversify their business activities, so they may face difficulties in terms of agency and poor corporate governance, which can lead to systemic risk (Boyd \& Runkle, 1993). Large banks can take advantage of scale by diversifying products so as to attract more customers, thereby reducing information costs as well as asymmetric information problems. The larger scale also helps banks to reduce transaction costs and participate in financing 
projects with high profitability, thereby increasing profitability (Boyd \& Runkle, 1993). In this case, the positive correlation between size and profitability reveals significant economies of scale. Empirical studies of Bourke (1989), Goddard, Molyneux and Wilson (2004) and Molyneux and Thornton (1992) supported this theory. By increasing the scale, banks could achieve marginal cost savings, especially as markets develop (Athanasoglou et al., 2008; Berger, Hanweck, \& Humphrey, 1987; Boyd \& Runkle, 1993; Miller \& Noulas, 1997).

However, the adverse correlation may occur in extremely large size banks, implying diseconomies of scale. It is because of potential liquidity difficulties and other threats that huge banks may face (Nguyen \& Nguyen, 2018). Large banks cannot benefit from diversification because of agency problems and defective corporate governance (Berger et al., 1987; Bolton, Freixas, \& Shapiro, 2007; Laeven \& Levine, 2007; Micco, Panizza, \& Yanez, 2007). Diversification may cause revenue fluctuation, implying high risks associated with these activities, hence bank size may exhibit adverse effect on profitability (Sufian \& Chong, 2008). Large and intensively diversified banks are more probable to obtain poor revenue, whereas small and specialised banks can efficiently diminish asymmetric information issues related to lending activities (Barros, Ferreira, \& Williams, 2007).

In ASEAN, bank size was found to have a positive impact on bank performance in Malaysia, which indicates that large banks tend to earn higher profits and obtain economies of scope (Lee, 2018; Trofimov et al., 2018). Big banks have more resources and opportunities to access efficient technologies so as to reap more incomes. However, huge banks in the Philippines and Vietnam have suffered diseconomies of scale (Nguyen \& Nguyen, 2018; Sufian \& Chong, 2008), whereas for Indonesian banks, there is no impact of total assets size on profitability (Ghalib, 2018; Lutfi \& Suyatno, 2019).

From the various views above, we propose two hypotheses:

Hypothesis 2a: There is a positive impact of bank size on bank performance.

Hypothesis $2 \mathrm{~b}$ : There is a negative impact of bank size on bank performance.

Besides that, to make the relationship between credit risk, bank size and bank performance clearer, we use a dummy variable based on bank size classification. Thus, we formulate two hypotheses:

Hypothesis 3a: The impact of credit risk on bank performance tends to be slighter in large banks than in small ones.

Hypothesis 3b: The impact of credit risk on bank performance tends to be stronger in large banks than in small ones.

To some extent, large banks experience high profitability thanks to economies of scale advantages. However, exceeding a certain threshold point in size, diseconomies of scale may arise because extremely large scale might cause negative effects due to bureaucratic and other reasons. Hence, the size-profitability relationship is expected to be non-linear (Athanasoglou et al., 2008; Dietrich \& Wanzenried, 2011; Sufian \& Chong, 2008). Eichengreen and Gibson (2001) suggested a U-shaped size-profitability relationship in Greece: small banks may obtain benefits of economies of scale when 
expanding in size, but large banks no longer enjoy economies of scale because of high costs. Recently, in a research in Indonesia, Lutfi and Suyatno (2019) found that bank size expansion will help banks enjoy economies of scope up to a certain point, after which any further extension will induce diseconomies of scope. Hence, in this situation, we hypothesise the following relationship:

Hypothesis 4: There is a non-linear impact of bank size on bank performance.

\section{Methodology and Data}

In order to examine the relationship between bank size, credit risk and bank profitability, this paper employs an unbalanced dataset of 31 Vietnamese commercial banks from 2009 to 2018. The estimated model and utilised variables are as follows:

$$
Y_{i t}=\alpha+Y_{i t-1}+\beta_{j} X_{j, i t}+\sum_{k=1}^{K} \beta_{k} X_{k, i t}+\sum_{l=1}^{L} \beta_{l} X_{l, i t}+u_{i t}
$$

where $i$ denotes the bank, $t$ denotes time period, $u$ is the disturbance term, $Y_{i t}$ is the proxy of profitability of bank $i$ at year $t$, and $X_{i t}$ are the explanatory variables which are grouped into credit risk $X_{j, i t}$, bank specific factors $X_{k, i t}$, macroeconomic factors $X_{l, i t}$. Table 1 illustrates the variables.

To proxy for bank profitability, returns on assets (ROA) and returns on equity (ROE) are the traditional and widely used measurements. While ROA may be the most important indicator reflecting the assets' management capacity to generate incomes of a bank (Dietrich \& Wanzenried, 2011), ROE measures the financial return shareholders gained from net income which is useful for investors in comparing between different industries or business sectors (ECB, 2010). However, ROA is perhaps misleading because of off-balance sheet (OBS) activities (Trujillo-Ponce, 2013). OBS refers to banking commitments and transactions not recorded in the traditional balance sheet. There are four categories of OBS activities, namely guarantees and equivalent contingent liabilities, commitments, market related transactions and advisory, management and underwriting functions (BIS, 1986). When comparing bank performance with and without OBS, most studies indicated that disregarding OBS may lead to unreliable conclusions (Clark \& Siems, 2002; Rogers, 1998). Apart from the suggestion of de Bandt, Camara, Maitre and Pessarossi (2018) on measuring CAPOBS which is defined as Capital/ (Total Assets + OBS), we propose a new measurement for bank profitability, namely $\mathrm{ROA}^{\mathrm{OBS}}$, that includes $\mathrm{OBS}$ items in the denominator. There are some reasons for this suggestion. These include OBS items bringing about non-interest revenues for banks (Angbazo, 1997), OBS activities slightly enhancing bank profitability (Avery \& Berger, 1991), and based on Basel II, OBS items will be converted into credit equivalents and considered as risk weight assets. From these points of view, we propose the following calculation:

$$
R O A^{O B S}=\frac{\text { After tax net income }}{\text { Total Assets }+ \text { Conversion value of } O B S}
$$

where: Conversion value of OBS = OBS items $\times$ Credit Conversion Factor (CCF) 
Following the State Bank of Vietnam's guidance from circulars number 36/2014/ TT-NHNN and 41/2016/TT-NHNN (SBV, 2014; 2016) as well as the current status of Vietnamese banks' annual financial reports, we have classified OBS into two groups:

(a) Group 1 includes contract execution guarantees, tender guarantees and other guarantees. This group has $\mathrm{CCF}=50 \%$.

(b) Group 2 includes guarantees of credit return, guarantees of payment, confirmation of letters of credit, commitments to foreign exchange transactions and other commitments. This group has CCF $=100 \%$.

To proxy for credit risk, this article employs the ratio of loan loss provisions (LLP) to total loans which indicates the bank's lending quality. LLP is used to compensate for the potential loan losses if credit risk exposure occurs (Ahmed, Takeda, \& Thomas, 1999). If banks lack the capability to control their lending activities or operate in hazardous markets, they will probably experience high loan loss provisions. A bank experiencing high loan loss provisions may be exposed to high risky loans and low profitability as well (Miller \& Noulas, 1997). Thus, this ratio has an expected negative impact on bank profitability. In Vietnam, LLP is more reliable than non-performing loan due to the fact that the disclosure of information in financial statements is more transparent.

Concerning bank size, LNTA, measured by natural logarithm of total assets, may have non-linear correlation to bank profitability. Large banks may obtain economies of scale advantages thanks to diversification and too-big-to-fail theory, thus their profitability could be improved. However, extremely large size banks may experience a negative impact on bank profitability because of agency costs, overheads of bureaucratic processes and other managing costs (Dietrich \& Wanzenried, 2011). Besides, we also build a dummy variable, namely SIZEdum, to compare profitability between big and small banks; and interactive variable between bank size and credit risk, namely SIZEdum*LLP, to examine the differential impact of credit risk on profitability between huge and small ones. SIZEdum is assigned the value of 1 if the total assets are higher than VND100 trillions, and 0 if otherwise (SBV, 2018). Finally, in order to determine whether the correlation between bank size and profitability is a non-linear relationship, we employ the square of LNTA (LNTA2) in this study.

With regard to internal factors influencing bank profitability, loans to assets (LA) has an expected positive sign because loans bring about the main revenue resources for banks (Trujillo-Ponce, 2013). Loans to assets ratio has been used as a measurement of liquidity and lending specialisation which tends to have a positive relationship in correlation to bank performance (Liu \& Wilson, 2010). Capital strength (ETA) may have mixed expected signs. Low ETA may help the bank to improve its income thanks to financial leverage (Dietrich \& Wanzenried, 2011). By contrast, banks with high ETA may increase their profitability by reducing loan rate and failure dimension of borrowers (Trujillo-Ponce, 2013). The revenue Herfindahl Hirschman Index (HHI) is employed in the model with the expected sign being negative, indicating that concentration of revenue sources is associated with low profitability, and diversification brings about high revenues for banks (Mercieca, Schaeck, \& Wolfe, 2007). The adverse relationship also suggests that diversification brings about high revenue for banks. A bank with high collapse probability (ZSCORE) means low risk level and hence, high profitability 
(Mercieca et al., 2007; Nguyen \& Nguyen, 2018). However, a bank with high level of loans and revenue diversification could reveal a negative relationship between ZSCORE and profitability (Mercieca et al., 2007; Stiroh, 2004). So, the expected sign for this variable may be positive or negative.

Turning to external factors, three-bank concentration (CR3) is chosen with positive expected sign following the structure conduct performance (SCP) hypothesis (Molyneux \& Thorton, 1992). In a high level of market concentration, banks may get high monopoly earnings (Dietrich \& Wanzenried, 2011). So, this indicator is expected to have a positive impact on Vietnamese banks' performance. Banks' activities are affected by macroeconomic fluctuations, especially economic development (GDP) and inflation (INF). Economic development is expected to boost bank performance because when the economy grows, the demand for banking activities may escalate which leads to improved bank profitability (Athanasoglou et al., 2008; Trujillo-Ponce, 2013). The impact of inflation depends on whether it is anticipated or not (Trujillo-Ponce, 2013). When the bank's profits grow speedily rather than its costs, inflation may bring about a positive impact on performance. Conversely, a harmful effect may occur if its costs escalate more rapidly than its income.

Table 1 reports the measurements and the literature sources of the variables employed in the estimations. The expected signs of the explanatory variables are also mentioned, where $(+)$ sign means positive effect, $(-)$ sign means negative effect, and $(+/-)$ sign means no obvious impact.

Table 1. Description of the variables

\begin{tabular}{|c|c|c|c|}
\hline Variables & Description & $\begin{array}{l}\text { Expected } \\
\text { sign }\end{array}$ & References \\
\hline \multicolumn{4}{|c|}{ Dependent variables } \\
\hline \multirow{2}{*}{$\mathrm{ROA}^{\mathrm{OBS}}$} & After tax net income & & \multirow[b]{3}{*}{$\begin{array}{l}\text { Athanasoglou et al. (2008), Lee et al. } \\
\text { (2014) }\end{array}$} \\
\hline & Total assets + Conversion value of OBS & & \\
\hline ROE & $\frac{\text { After tax net income }}{\text { Equity }}$ & & \\
\hline \multicolumn{4}{|c|}{ Independent variables } \\
\hline LLP & $\frac{\text { Loan loss provisions }}{\text { Total loans }}$ & - & $\begin{array}{l}\text { Angbazo (1997), Athanasoglou et al. } \\
\text { (2008), Lee et al. (2014), Miller \& } \\
\text { Noulas (1997), Sufian \& Chong } \\
\text { (2008) }\end{array}$ \\
\hline LNTA & Natural logarithm of total assets & $+/-$ & $\begin{array}{l}\text { Athanasoglou et al. (2008), } \\
\text { Chiorazzo, Milani, \& Salvini (2008), } \\
\text { Dietrich \& Wanzenried (2011), Miller } \\
\text { \& Noulas (1997), Sufian \& Chong } \\
\text { (2008) }\end{array}$ \\
\hline LNTA $^{2}$ & $\begin{array}{l}\text { The square of natural logarithm of } \\
\text { total assets }\end{array}$ & $+/-$ & $\begin{array}{l}\text { Athanasoglou et al. (2008), } \\
\text { Eichengreen \& Gibson (2001) }\end{array}$ \\
\hline
\end{tabular}


Table 1. Continued

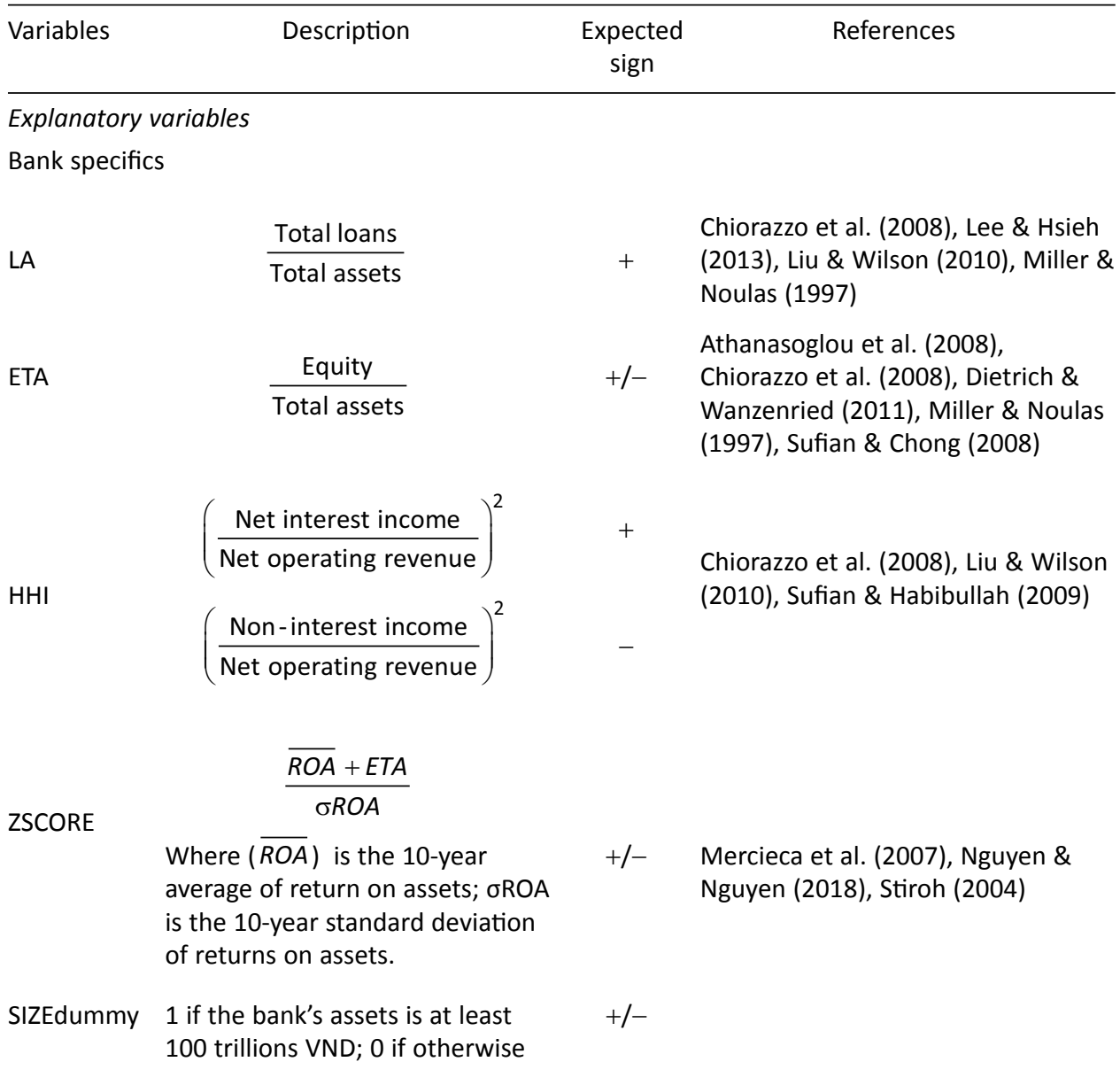

Macroeconomic factors

CR3 Three largest banks asset concentration ratio

Athanasoglou et al. (2008),

$+\quad$ Dietrich \& Wanzenried (2011),

Kosmidou (2008), Liu \& Wilson

(2010), Pervan et al. (2015)

Athanasoglou et al. (2008), Sufian \&

INF

Rate of inflation

$+1-$

Chong (2008), Pervan et al. (2015),

Sufian \& Habibullah (2009),

GDP Annual growth rate of gross

domestic product

$+\quad$ Dietrich \& Wanzenried (2011), Lee \& Hsieh (2013), Liu \& Wilson (2010), Pervan et al. (2015), Sufian \& Chong (2008)

Source: Authors. 
Bank specific data were collected from Vietstock Financial Data Company database of 31 Vietnamese commercial banks from 2009 to 2018. Data on macroeconomic factors were collected from the World Bank database. Outliers are removed to ensure reliable outcomes.

To address potential endogeneity, heteroskedasticity and autocorrelation problems, the generalized method of moments (GMM) technique suggested by Arellano and Bover (1995) and Blundell \& Bond (1998) may be the suitable estimator approach. There are two estimators for GMM dynamic panel models: difference GMM and system $\mathrm{GMM}$, in which the latter is more efficient than the former because it combines the regression difference with the regression in levels, hence reducing the potential biases and imprecision (Arellano \& Bover, 1995; Lee \& Hsieh, 2013). GMM estimators have one- and two-step variants, but the second one is generally more reliable than the first one, especially for the system GMM (Lee \& Hsieh, 2013; Nguyen D.T. \& Nguyen H.T.K., 2018; Windmeijer, 2005). Hence, the two-step system GMM should be exploited in this paper. We also use Sargan (Arellano \& Bond, 1991) and Hansen test (Blundell \& Bond, $1998)$ to test the suitability of employed instruments: Arellano-Bond tests (AR(1) and $A R(2))$ to test autocorrelation error.

\section{Results and Discussions}

\subsection{Descriptive Statistics}

Table 2 illustrates the descriptive statistics of employed variables including their mean, standard deviation, minimum and maximum values. As can be seen from this table, ROAOBS has a value fluctuating from $0.0256 \%$ to $1.6187 \%$ and takes the average amount of $0.6793 \%$. ROE reaches its highest value at $21.689 \%$, drops to its lowest value at $0.5170 \%$ and has the average amount of $8.5166 \%$. The mean of LLP is $1.2517 \%$ and it ranges between $0.7252 \%$ and $2.0336 \%$. LNTA fluctuates from 15.02 to 21 and has a mean value of 18.185. Other variables are represented in Table 2.

Table 2. Descriptive statistics

\begin{tabular}{lcccrr}
\hline Variables & Obs. & Mean & Std. Dev. & Min & Max \\
\hline ROA $^{\text {OBS }}$ & 294 & 0.6793 & 0.4600 & 0.0256 & 1.6187 \\
ROE & 294 & 8.5166 & 5.9963 & 0.5170 & 21.689 \\
LLP & 295 & 1.2517 & 0.3931 & 0.7252 & 2.0336 \\
LNTA & 295 & 18.185 & 1.1613 & 15.02 & 21 \\
LA & 295 & 0.5294 & 0.1316 & 0.1448 & 0.806 \\
ETA & 295 & 9.7003 & 3.8966 & 3.2572 & 18.453 \\
HHI & 294 & 0.7319 & 0.1546 & 0.5 & 0.9902 \\
ZSCORE & 295 & 25.863 & 13.155 & 2.4155 & 56.536 \\
CR3 & 310 & 40.267 & 6.1524 & 25.884 & 50.498 \\
INF & 310 & 6.1365 & 3.5955 & 0.88 & 13.885 \\
GDP & 310 & 6.1497 & 0.6016 & 5.2474 & 7.08 \\
\hline
\end{tabular}


Table 3. Correlation coefficient matrix

\begin{tabular}{llllllllll}
\hline & LLP & LNTA & LA & ETA & HHI & ZSCORE & CR3 & INF & GDP \\
\hline LLP & 1.000 & & & & & & & \\
LNTA & $0.262^{* * *}$ & 1.000 & & & & & & & \\
LA & $-0.119^{* *}$ & $0.212^{* * *}$ & 1.000 & & & & & & \\
ETA & -0.080 & $-0.732^{* * *}$ & -0.075 & 1.000 & & & & & \\
HHI & -0.033 & $-0.205^{* * *}$ & -0.004 & 0.076 & 1.000 & & & & \\
ZSCORE & $0.216^{* * *}$ & -0.040 & -0.066 & $0.246^{* * *}$ & -0.080 & 1.000 & & & \\
CR3 & -0.060 & -0.069 & 0.013 & 0.084 & -0.015 & 0.054 & 1.000 & & \\
INF & $0.160^{* * *}$ & $-0.253^{* * *}$ & $-0.316^{* * *}$ & $0.267^{* * *}$ & $0.155^{* * *}$ & $0.179^{* * *}$ & $-0.226^{* * *}$ & 1.000 & \\
GDP & $-0.180^{* * *}$ & $0.269^{* * *}$ & $0.216^{* * *}$ & $-0.271^{* * *}$ & -0.070 & $-0.184^{* * *}$ & -0.067 & $-0.422^{* * *} 1.000$ \\
\hline
\end{tabular}

Note: This table provides information on the correlation between the explanatory variables employed in this paper. ${ }^{* *},{ }^{* *}$, and ${ }^{*}$ indicate statistical significance at $1 \%, 5 \%$ and $10 \%$ levels respectively.

Table 3 indicates the correlation coefficient matrix between explained variables to examine the multicollinearity issue. This issue may occur between ETA and LNTA (73.2\%), but this problem may be safely ignored because the chosen regression model is GMM.

\subsection{Regression Analysis}

Table 4 reports the regression outcomes extracted from Stata estimator. The Ramsey RESET tests suggest that there are no omitted variables ( $p$-value $>0.05$ ). F-tests show that all models are significant ( $p$-value $<0.05)$. Sargan and Hansen tests ( $p$-value $>0.05$ ) indicate that the two-step S-GMM is the appropriate estimator. $A R(1)$ tests ( $p$-value $<0.05)$ and $A R(2)(p$-value $>0.05)$ tests suggest that there is no autocorrelation issue.

The regression results showed that the lagged value of dependent variables is significantly positive, suggesting that current profitability is affected by profitability in the previous year. The significantly high correlations of lagged profitability variables confirm the dynamic character of the model specification.

As expected, the outcomes reveal a negative correlation between credit risk (LLP) and bank profitability in all models, indicating that banks with high level of accumulation provisions, meaning high level of problem loans, may cause harmful effect on bank profitability. This finding supports Hypothesis $1 \mathrm{~b}$ and is in line with previous studies by researchers such as Ahmed et al. (1999), Athanasoglou et al. (2008), Dietrich and Wanzenried (2011), Kosmidou (2008), Nguyen and Nguyen (2018) and Trujillo-Ponce (2013). In fact, the Vietnamese banking system has recently experienced an increase in non-performing loans as a consequence of over credit expansion. The establishment of the Vietnam Asset Management Company (VAMC) has helped banks to reduce their problem loans, but in return, banks have to keep VAMC special bonds and provision for these bonds. As a result, these provisions will erode the before tax incomes, leading to profitability reduction. 
Table 4. Regression results

\begin{tabular}{|c|c|c|c|c|c|c|}
\hline \multirow{2}{*}{$\begin{array}{l}\text { Dependent variable } \\
\text { Model }\end{array}$} & \multicolumn{3}{|c|}{$\mathrm{ROA}^{\mathrm{OBS}}$} & \multicolumn{3}{|c|}{ ROE } \\
\hline & (1) & (2) & (3) & (4) & (5) & (6) \\
\hline $\mathrm{ROA}^{\mathrm{OBS}}{ }_{\mathrm{t}-1}$ & $0.3465^{* * *}$ & $0.4213^{* * *}$ & $0.6429^{* * *}$ & & & \\
\hline $\mathrm{ROE}_{\mathrm{t}-1}$ & & & & $0.6168^{* * *}$ & $0.5664^{* * *}$ & $0.7476^{* * *}$ \\
\hline LLP & $-0.1288^{* * *}$ & $-0.3496^{* * *}$ & $-0.0902^{* *}$ & $-1.5710^{* * *}$ & $-4.2343^{* * *}$ & $-1.1450^{* *}$ \\
\hline LNTA & $-0.0510^{* * *}$ & & $0.1187^{*}$ & $-0.3353^{* *}$ & & $1.7418^{*}$ \\
\hline LNTA $^{2}$ & & & $-0.0060^{*}$ & & & $-0.0763^{*}$ \\
\hline LA & $0.6514^{* * *}$ & $0.6011^{* * *}$ & $0.3122^{* *}$ & $8.6627^{* * *}$ & $6.7117^{* *}$ & $4.3203^{* *}$ \\
\hline ETA & $-0.0330^{* * *}$ & $-0.0334^{*}$ & $-0.0384^{* *}$ & $-0.3874^{* *}$ & -0.0320 & $-0.5391^{* * *}$ \\
\hline $\mathrm{HHI}$ & $-0.6025^{* *}$ & $-0.6049^{* * *}$ & $-0.8833^{* * *}$ & $-8.2358^{* * *}$ & $-16.768^{* * *}$ & $-9.8721^{* * *}$ \\
\hline ZSCORE & $0.0215^{* * *}$ & $0.0132^{*}$ & $0.0047^{*}$ & $0.1515^{* * *}$ & 0.0496 & $0.0405^{*}$ \\
\hline CR3 & $0.0024^{* *}$ & 0.0004 & $0.0021^{* *}$ & $-0.0448^{* *}$ & $-0.0459^{* *}$ & $-0.0404^{* * *}$ \\
\hline INF & $0.0537^{* * *}$ & $0.0515^{* * *}$ & $0.0307^{* * *}$ & $0.3165^{* * *}$ & $0.4027^{* * *}$ & $0.1674^{* *}$ \\
\hline GDP & $0.1432^{* * *}$ & $0.0919^{* * *}$ & $0.0974^{* * *}$ & $1.9677^{* * *}$ & $2.6445^{* * *}$ & $1.0821^{* * *}$ \\
\hline SIZEdum & & $-0.4843^{* *}$ & & & $-3.7938^{* *}$ & \\
\hline SIZEdum*LLP & & $0.3684^{* * *}$ & & & $3.5853^{* * *}$ & \\
\hline Ramsey RESET test & 0.4480 & 0.1347 & 0.3854 & 0.7036 & 0.4942 & 0.5344 \\
\hline No. of groups & 31 & 31 & 31 & 31 & 31 & 31 \\
\hline No. of instruments & 31 & 30 & 31 & 31 & 31 & 31 \\
\hline F-test ( $p$-value) & 0.000 & 0.000 & 0.000 & 0.000 & 0.000 & 0.000 \\
\hline Sargan test & 0.359 & 0.885 & 0.813 & 0.504 & 0.574 & 0.485 \\
\hline Hansen test & 0.476 & 0.491 & 0.399 & 0.580 & 0.466 & 0.694 \\
\hline$A R(1)$ & 0.002 & 0.007 & 0.003 & 0.003 & 0.005 & 0.003 \\
\hline$A R(2)$ & 0.489 & 0.594 & 0.670 & 0.802 & 0.152 & 0.205 \\
\hline
\end{tabular}

Note: This table provides estimation results on the correlation between bank size, credit risk and bank profitability in Vietnam by two-step system GMM approach. Models (1) to (3) have the dependent variable is ROA, (4) to (5) have the dependent variable is ROE. Models (2) and (5) have the participation of dummy and interaction variables (SIZEdum and SIZEdum*LLP) but there is no LNTA variable present. Models (3) and (6) present a nonlinear relationship between bank size and profitability. We instrument for all regressors except for such variables as ETA, HHI, ZSCORE which are clearly exogenous. The robustness of these results have been checked by using the dependent variable of traditional ROA as well as replacing the variable of credit risk with the ratio of non-performing loans. ${ }^{* * *},{ }^{* *}$, and ${ }^{*}$ indicate statistical significance at the $1 \%, 5 \%$ and $10 \%$ levels respectively.

Regarding internal factors, LA has a positive impact on profitability as expected, indicating that Vietnamese banks have pursued a strategy of boosting lending to make a profit from interest. This finding is consistent with other authors such as Chiorazzo et al. (2008), García-Herrero, Gavilá and Santabárbara (2009), Trujillo-Ponce (2013). In recent years, Vietnamese banks have expanded their credit activities to boost their financial strength due to competitive pressure from increasing foreign banks and potential threats arising from the restructuring of the banking system as well. Although bad loans tend to increase, the interest revenues generated from lending activities have improved the banks performance in recent years. 
The negative coefficient of ETA reveals that banks with more equity may lead to a reduction of external debts, so they cannot obtain benefits from financial leverage. During this period, Vietnamese domestic commercial banks were restructured to adapt to Basel II by increasing capital, hence they should attempt to achieve their optimal captital level. $\mathrm{HHI}$ has a significantly adverse effect on profitability in all models, suggesting that diversification brings about benefits for Vietnamese banks. Vietnamese banks have expanded their activities into non-traditional banking activities which generate substantial non-interest income for them. Banks with multifarious activities are likely to gain more profits due to economies of scope. Nguyen and Nguyen (2018) had the same result when examining non-interest income as a determinant of bank performance in Vietnam. As generally acknowledged, an increasing ZSCORE denotes sound financial condition, hence ZSCORE has a positive impact on profitability.

With regard to external factors, the coefficient of CR3 has mixed results. CR3 has a favourable impact in relation to profitability (ROAOBS) which supports the SCP theory (also regarded as the market-power hypothesis), meaning that Vietnamese banks may obtain monopolistic profits from the market. A more concentrated market favours bank profitability motivated by the benefits of greater market power (Trujillo-Ponce, 2013). However, the adverse effect of CR3 on ROE implies that in a higher concentration market, the bank might suffer from tougher competition which in turn adversely affects profitability (Boone \& Weigand, 2000). Concerning macroeconomic factors, all variables have positive relationship with the dependent variable. The majority of income sources of Vietnamese banks come from the domestic market, so GDP improves bank profitability. Besides, the inflation rate is anticipated at the beginning of the year by the State Bank of Vietnam, so the interest rate is adjusted timely, thus INF has a positive impact on Vietnamese banks profitability.

\section{(i) Bank Size and the Relationship between Credit Risk and Bank Profitability}

The negative impact of LNTA on dependent variables in models (1) and (4) supports Hypothesis $2 \mathrm{~b}$. This outcome suggests that Vietnamese banks capture diseconomies of scale because of reasons such as agency costs, expenses of bureaucratic processes and other managing costs (Dietrich \& Wanzenried, 2011). However, LNTA has a positive impact on ROE (model 5), suggesting that bank size expansion may help im-prove shareholder's return. Moving to the dummy variable, SIZEdum has an inverse correlation to bank performance which is in agreement with the sign of LNTA as well as Hypothesis $2 \mathrm{~b}$ but this correlation is insignificant in model 5 . In fact, large banks in Vietnam participate in long-term risky lending projects according to government nominations. They are supported and prioritised by the government through preferential policies, cross-ownership, and appointment of experienced board members from senior management agencies; hence taking part in many risky activities as well as expanding their branches nationwide. Thus, dependent psychology and operational expenses maybe acceptable explanations for less efficient performance in big banks. Small banks in Vietnam have performed more efficiently recently in order to survive under competition pressure and restructuring requirements. Progress in the restructuring of the banking system in recent years forces small banks to increase their 
capital as well as improve their financial performance. Their small scale also helps banks spend less on management costs and are more cautious with high-risk loans as well.

The interactive variable SIZEdum*LLP has a positive impact on dependent variables at $1 \%$ significance level, suggesting that the harmful effect of credit risk in large banks tends to be slighter than in small ones. Hence, Hypothesis $3 a$ is affirmed. A reasonable explanation for this may be the lower lending interest rate in larger banks in comparison with the smaller ones in Vietnam. Most of the large banks in Vietnam have supplied low lending rates thanks to their reputation, market power and government sponsorship. Borrowers can benefit from the low loan rates as long as they meet the bank's requirements which force them to act in accordance with the bank's expectations. Because of the lower lending rate, borrowers are expected to reimburse on time, thus the credit risk may be reduced. Besides, the cheaper information cost is also one of the favourable characteristics that the huge Vietnamese banks may enjoy. With the expansion of branches, they are able to collect more information from their partners concerning potential customers. Hence, the banks can evaluate the potential capability reimbursement of their customers. Vietnamese big banks have higher opportunities to obtain the effective risk management system as well as access to modern technology. Big banks can achieve intensive financial power in order to experience international standardisations such as the Basel standard, and the International Financial Reporting Standards (IFRS). They can also attain modern technology by approaching the 4.0 Revolution or core banking more easily. So, their credit risk control mechanism will improve which helps to reduce the impact of this risk on bank profitability as a result.

\section{(ii) The Non-linear Relationship between Bank Size and Bank Profitability}

As expected, the regression outcomes from models (3) and (6) illustrate that there is a non-linear relationship between bank size and bank performance in the inverted U-shape. It means bank size has improved bank profitability until it reaches the optimal threshold, which then results in decreasing profitability. Thus, with respect to Hypothesis 4, this inverted U-shape relationship confirms our expectation. This result also coincides with previous studies of Eichengreen and Gibson (2001), and Lutfi and Suyatno (2019). Eichengreen and Gibson (2001) pointed out the bellshaped relationship between bank size and profitability, suggesting that profitability increases and then decreases, and the threshold point is nearby mean value. However, Athanasoglou et al. (2008) employed both logarithm of assets and their square to capture the non-linear relationship with bank profitability, but the outcomes showed that the effect of bank size is not important.

In Vietnam, under competitive pressure and demanding financial strength, small and medium size banks usually attempt to grow faster, receive economies of scale advantages and raise profits if they become larger. Vietnamese banks have to adapt to Basel II in 2020, thus small banks ought to be more active in raising profitability to meet this standard. Large Vietnamese banks having taken full advantage of their scale, bulky and scattered apparatus are unable to control resources, resulting in inefficiencies in their operations. In addition, the process of restructuring the banking system resulted 
in a strong wave of mergers in Vietnam which has led to the formation of newly large established banks. In the early years, they have focused on attaching importance to organisational stability and expanding market share rather than improving profitability. So, these reasons may help to explain the non-linear relationship between bank size and bank profitability in Vietnam.

\section{Conclusion}

By using an unbalanced panel dataset and two-step system GMM estimator, this study contributes empirical evidence on the relationship between bank size, credit risk and bank profitability in Vietnam from 2009 to 2018. By employing off-balance sheet items in the denominator when calculating return on assets, this paper highlights the role of OBS in generating non-interest income as well as contributes to the literature of profitability measurement. The outcomes show that there is a significant adverse relationship between credit risk and bank profitability, but this harmful effect tends to decrease in larger size banks. The negative correlation between bank size and profitability indicates that large banks tend to perform inefficiently compared to small banks. This article detects a non-linear relationship between bank size and profitability in the Vietnamese banking sector, implying that bank size has improved bank profitability until it reaches the optimal threshold, which then leads to decreasing profitability. Thus, Vietnamese banks should pay more attention to increasing their size to get advantages from scale, especially in the next restructuring wave to adapt to Basel

II. The regression results also reveal that current profitability is affected by profitability in the previous year. Vietnamese banks' profitability depends much on lending activities, but diversification brings about other benefits as well.

Even though our article may probably be the latest study considering the relationship between bank size, credit risk and profitability in Vietnam, it has certain limitations. First, there may be a non-linear relationship between credit risk and bank profitability. Second, foreign banks are not covered in the sample to compare this relationship between domestic banks and foreign ones. Third, expanding the scope of research, such as to Southeast Asian nations or emerging nations, would help us to understand comprehensively about this correlation in different countries with different economic conditions. Some of these issues will be addressed in future work.

\section{References}

Ahmed, A.S., Takeda, C., \& Thomas, S. (1999). Bank loan loss provisions: A reexamination of capital management, earnings management and signaling effects. Journal of Accounting and Economics, 28(1), 1-25. https://doi.org/10.1016/S0165-4101(99)00017-8

Ammar, N., \& Boughrara, A. (2019). The impact of revenue diversification on bank profitability and risk: Evidence from MENA banking industry. Macroeconomics and Finance in Emerging Market Economies, 12(1), 36-70. https://doi.org/10.1080/17520843.2018.1535513

Angbazo L. (1997). Commercial bank net interest margins, default risk, interest-rate risk, and off-balance sheet banking. Journal of Banking and Finance, 21(1), 55-87. https://doi.org/ 10.1016/S0378-4266(96)00025-8 
Arellano, M., \& Bond, S. (1991). Some tests of specification for panel data: Monte Carlo evidence and an application to employment equations. Review of Economic Studies, 58(2), 277-297. https://doi.org/10.2307/2297968

Arellano, M., \& Bover, O. (1995). Another look at the instrument variable estimation of errorcomponents models. Journal of Econometrics, 68(1), 29-51. https://doi.org/10.1016/03044076(94)01642-D

Athanasoglou, P.P., Brissimis, S.N., \& Delis, M.D. (2008). Bank-specific, industry-specific and macroeconomic determinants of bank profitability. Journal of International Financial Markets, Institutions and Money, 18(2), 121-136. https://doi.org/10.1016/j.intfin.2006.07.001

Avery, R.B., \& Berger, A.N. (1991). Loan commitments and bank risk exposure. Journal of Banking \& Finance, 15(1), 173-192. https://doi.org/10.1016/0378-4266(91)90045-N

Bank for International Settlements (BIS). (1986). The management of banks' off-balance-sheet exposures: A supervisory perspective. Basel, Switzerland: Author. Retrieved from https:// www.bis.org/publ/bcbsc134.htm

Barros, C.P., Ferreira, C., \& Williams, J. (2007). Analysing the determinants of performance of best and worst European banks: A mixed logit approach. Journal of Banking \& Finance, 31(7), 2189-2203. https://doi.org/10.1016/j.jbankfin.2006.11.010

Basel Committee on Banking Supervision. (2000). Principles for the management of credit risk. Washington, D.C.: Author. Retrieved from https://www.bis.org/publ/bcbs75.htm

Batten, J., \& Vo, X.V. (2019). Determinants of bank profitability-evidence from Vietnam. Emerging Markets Finance and Trade, 55(6), 1417-1428. https://doi.org/10.1080/154049 6X.2018.1524326

Berger, A.N., \& DeYoung, R. (1997). Problem loans and cost efficiency in commercial banks. Journal of Banking \& Finance, 21(6), 849-870. https://doi.org/10.1016/s0378-4266(97) 00003-4

Berger, A.N., Hanweck, G.A., \& Humphrey, D.B. (1987). Competitive viability in banking: Scale, scope, and product mix economies. Journal of Monetary Economics, 20(3), 501-520. https:// doi.org/10.1016/0304-3932(87)90039-0

Blundell, R., \& Bond, S. (1998). Initial conditions and moment restrictions in dynamic panel data models. Journal of Econometrics, 87(1), 115-143. https://doi.org/10.1016/S0304-4076(98) 00009-8

Boahene, S., Dasah, J., \& Agyei, S. (2012). Credit risk and profitability of selected banks in Ghana. Research Journal of Finance and Accounting, 3(7), 6-14.

Bolton, P., Freixas, X., \& Shapiro, J. (2007). Conflicts of interest, information provision and competition in the financial services industry. Journal of Financial Economics, 85(2), 297-330. https://doi.org/10.1016/j.jfineco.2005.06.004

Boone, J., \& Weigand, J. (2000). Measuring competition: How are cost differentials mapped into profit differentials? (CPB Working Paper No. 131), The Hague, Netherlands: CPB Netherlands Bureau for Economic Policy Analysis. Retrieved from https://www.cpb.nl/sites/default/files/ publicaties/download/measuring-competition-how-are-cost-differentials-mapped-profitdifferentials.pdf

Bourke, P. (1989). Concentration and other determinants of bank profitability in Europe, North America and Australia. Journal of Banking \& Finance 13(1), 65-79. https://doi.org/10.1016/ 0378-4266(89)90020-4

Boyd, J.H., \& Runkle, D.E. (1993). Size and performance of banking firms: Testing the predictions of theory. Journal of Monetary Economics, 31(1), 47-67. https://doi.org/10.1016/03043932(93)90016-9

Chiorazzo, V., Milani, C., \& Salvini, F. (2008). Income diversification and bank performance: Evidence from Italian banks. Journal of Financial Services Research, 33(3), 181-203. https:// doi.org/10.1007/s10693-008-0029-4 
Clark A.J., \& Siems, T.F. (2002). X-efficiency in banking: Looking beyond the balance sheet. Journal of Money, Credit and Banking, 34(4), 987-1013.

Coyle, B. (2000). Framework for credit risk management. Canterbury, Kent: Chartered Institute of Bankers, United Kingdom. Retrieved from https://www.nlb.gov.sg/biblio/9845592

de Bandt, O., Camara, B., Maitre, A., \& Pessarossi, P. (2018). Optimal capital, regulatory requirements and bank performance in times of crisis: Evidence from France. Journal of Financial Stability, 39, 175-186. https://doi.org/10.1016/j.jfs.2017.03.002

Dietrich, A., \& Wanzenried, G. (2011). Determinants of bank profitability before and during the crisis: Evidence from Switzerland. Journal of International Financial Markets, Institutions and Money, 21(3), 307-327. https://doi.org/10.1016/j.intfin.2010.11.002

Eichengreen, B., \& Gibson, H.D. (2001). Greek banking at the dawn of the new millennium (CEPR Discussion Paper 2791). Washington, DC: Center for Economic and Policy Research.

European Central Bank (ECB). (2010). Beyond ROE - How to measure bank performance. Frankfurt, Germany: Author. Retrieved from https://www.ecb.europa.eu/pub/pdf/other/ beyondroehowtomeasurebankperformance201009en.pdf

Farhi, E., \& Tirole, J. (2012). Collective moral hazard, maturity mismatch and systemic bailouts. American Economic Review 102(1), 60-93. https://doi.org/10.1257/aer.102.1.60

García-Herrero, A., Gavilá, S., \& Santabárbara, D. (2009). What explains the low profitability of Chinese banks? Journal of Banking \& Finance 33(11), 2080-2092. https://doi.org/-10.1016/j. jbankfin.2009.05.005

Ghalib, S. (2018). Good corporate governance rating and bank profitability in Indonesia: Evidence from panel data. International Journal of Business and Society, 19(3), 570-586.

Goddard, J., Molyneux, P., \& Wilson, J.O.S. (2004). The profitability of European banks: A cross sectional and dynamic panel analysis. Manchester School, 72(3), 363-381. https://doi.org/ 10.1111/j.1467-9957.2004.00397.x

Kosmidou, K. (2008). The determinants of banks' profits in Greece during the period of EU financial integration. Managerial Finance, 34(3), 146-159. https://doi.org/10.1108/0307 4350810848036

Kosmidou, K., Tanna, S., \& Pasiouras, F. (2005). Determinants of profitability of domestic UK commercial banks: Panel evidence from the period 1995-2002. Paper presented at the Money Macro and Finance (MMF) Research Group Conference 2005. Retrieved from https:// econpapers.repec.org/paper/mmfmmfc05/45.htm

Laeven, L., \& Levine, R. (2007). Is there a diversification discount in financial conglomerates? Journal of Financial Economics, 85(2), 331-367. https://doi.org/10.1016/j.jfineco.2005.06.001

Laeven, L., Ratnovski, L., \& Tong, H. (2016). Bank size, capital, and systemic risk: Some international evidence. Journal of Banking \& Finance, 69(S1), S25-S34. https://doi.org/10.1016/ j.jbankfin.2015.06.022

Lee, C.C., \& Hsieh, M.F. (2013). The impact of bank capital on profitability and risk in Asian banking. Journal of International Money and Finance, 32, 251-281. https://doi.org/10.1016/j. jimonfin.2012.04.013

Lee, C.C., Yang, S.J., \& Chang, C.H. (2014). Non-interest income, profitability, and risk in banking industry: A cross-country analysis. North American Journal of Economics and Finance, 27, 4867. https://doi.org/10.1016/j.najef.2013.11.002

Lee, S.P. (2018). Determinants of bank performance in Malaysia. Argumenta Oeconomica, 41(2), 311-335. https://doi.org/10.15611/aoe.2018.2.14

Liu, H., \& Wilson, J.O.S. (2010). The profitability of banks in Japan. Applied Financial Economics, 20(24), 1851-1866. https://doi.org/10.1080/09603107.2010.526577

Lutfi, \& Suyatno (2019). Determinants of bank efficiency: Evidence from Indonesian regional development banks using data envelopment analysis. Jurnal Ekonomi Malaysia, 53(3), 1-16. http://www.ukm.my/fep/jem/content/2019-3.html 
Mercieca, S., Schaeck, K., \& Wolfe, S. (2007). Small European banks: Benefits from diversification. Journal of Banking \& Finance, 31(7), 1975-1998. https://doi.org/10.1016/j. jbankfin.2007.01.004

Micco, A., Panizza, U., \& Yanez, M. (2007). Bank ownership and performance. Does politics matter? Journal of Banking \& Finance, 31(1), 219-241. https://doi.org/10.1016/j.jbankfin. 2006.02.007

Miller, S.M., \& Noulas, A.G. (1997). Portfolio mix and large bank profitability in the USA. Applied Economics, 29(4), 505-512. https://doi.org/10.1080/000368497326994

Molyneux, P., \& Thorton, J. (1992). The determinants of European bank profitability: A note. Journal of Banking \& Finance, 16(6), 1173-1178. https://doi.org/10.1016/0378-4266(92) 90065-8

Mongid, A., \& Muazaroh, M. (2017). On the nexus between risk taking and profitability: Evidences from Indonesia. International Journal of Business and Society, 18(2), 271-284.

Nguyen, D.T., \& Nguyen, H.T.K. (2018). Does a higher level of capital ensure lower risk for a bank? Evidence from the Vietnamese banking system. Malaysian Journal of Economic Studies, 55(2), 245-265. https://doi.org/10.22452/MJES.vol55no2.6

Nguyen, Hien Thi Kim, \& Nguyen, Dung Tien. (2018). Globalisation and bank performance in Vietnam. Malaysian Journal of Economic Studies, 55(1), 49-70. https://doi.org/10.22452/ MJES.vol55no1.3

Nguyen, H.P. (2018). Profitability of Vietnamese banks under competitive pressure. Emerging Markets Finance and Trade, 55(9), 2004-2021. https://doi.org/10.1080/1540496X.2018. 1511977

Olson, D., \& Zoubi, T.A. (2011). Efficiency and bank profitability in MENA countries. Emerging Markets Review, 12(2), 94-110. https://doi.org/10.1016/j.ememar.2011.02.003

Pervan, M., Pelivan, I., \& Arnerić, J. (2015). Profit persistence and determinants of bank profitability in Croatia. Economic Research-Ekonomska Istraživanja, 28(1), 284-298. https://doi. org/10.1080/1331677X.2015.1041778

Rogers, K.E. (1998). Nontraditional activities and the efficiency of US commercial banks. Journal of Banking \& Finance, 22(4), 467-482. https://doi.org/10.1016/S03784266(98)00020-X

State Bank of Vietnam (SBV). (2014). Circular number 36/2014/TT-NHNN stipulating minimum safety limits and ratios for transactions performed by credit institutions and branches of foreign banks. Hanoi, Vietnam: Author. Retrieved from https://thuvienphapluat.vn/van-ban/ Tien-te-Ngan-hang/Circular-No-36-2014-TT-NHNN-minimum-safety-limits-ratios-for-creditinstitutions-branches-foreign-banks-260324.aspx

State Bank of Vietnam (SBV). (2016). Circular number 41/2016/TT-NHNN prescribing the capital adequacy ratio for operations of banks and/or foreign bank branches. Hanoi, Vietnam: Author. Retrieved from https://vanbanphapluat.co/circular-41-2016-tt-nhnn-prescribingprudential-ratios-operations-banks-and-or-foreign-bank-branches

State Bank of Vietnam (SBV). (2018). Circular number 52/2018/TT-NHNN prescribing credit rating of credit institutions and foreign bank branches. Hanoi, Vietnam; Author. Retrieved from https://thuvienphapluat.vn/van-ban/Tien-te-Ngan-hang/Circular-52-2018-TT-NHNN-creditrating-of-credit-institutions-and-foreign-bank-branches-407499.aspx

Stiglitz, J.E., \& Weiss, A. (1981). Credit rationing in markets with imperfect information. American Economic Review, 71(3), 393-410. https://doi.org/10.7916/D8V12FT1

Stiroh, K.J. (2004). Do community banks benefit from diversification? Journal of Financial Services Research, 25(2/3), 135-160. https://doi.org/10.1023/B:FINA.0000020657.59334.76

Sufian, F., \& Chong, R.R. (2008). Determinants of bank profitability in a developing economy: Empirical evidence from the Philippines. Asian Academy of Management Journal of Accounting and Finance, 4(2), 91-112. 
Sufian, F., \& Habibullah, M.S. (2009). Determinants of bank profitability in a developing economy: Empirical evidence from Bangladesh. Journal of Business Economics and Management, 10(3), 207-217. https://doi.org/10.3846/1611-1699.2009.10.207-217

Trofimov, Ivan D., Md. Aris, Nazaria, \& Kho Ying Ying, Jovena (2018). Determinants of commercial banks' profitability in Malaysia (MPRA Paper, No. 85598). Munich, Germany: Munich University Library. Retrieved from https://mpra.ub.uni-muenchen.de/85598/

Trujillo-Ponce, A. (2013). What determines the profitability of banks? Evidence from Spain. Accounting \& Finance, 53(2), 561-586. https://doi.org/10.1111/j.1467629X.2011.00466.x

Vo, X.V. (2018). Bank lending behavior in emerging markets. Finance Research Letters, 27(December), 129-134. https://doi.org/10.1016/j.frl.2018.02.011

Windmeijer, F. (2005). A finite sample correction for the variance of linear efficient two-step GMM estimators. Journal of Econometrics, 126(1), 25-51. https://doi.org/10.1016/j.jeconom. 2004.02.005 
